\title{
Development of semi-synthetic catalyst based on clay and their use in catalytic cracking of petroleum residue
}

\author{
Oumarou Abdoulaye Dan Makaou ${ }^{1,2} \cdot$ Soumahoro Gueu $^{1}$ (D) $\cdot$ Marou Gourouza ${ }^{3} \cdot$ Kouassi Benjamin Yao $^{1}$
}

Received: 10 December 2020 / Accepted: 26 February 2021 / Published online: 9 March 2021

(c) The Author(s) 2021

\begin{abstract}
Two semi-synthetic clay-based catalysts were prepared. These catalysts were obtained by incorporating lanthanum oxide (Cat1) and chromium oxide (Cat2). They were then tested for catalytic cracking of a heavy petroleum residue (fuel). The two formulations were carried out in the presence of silica to improve their acidity then underwent an acid activation. The catalysts obtained were characterized by various methods (XRD, FTIR, ICP-OES, SEM). The results showed that the incorporation of oxides and the addition of silica improves the structural characteristics of the final products. The support used was a kaolinite rich clay, having a specific surface area of $15.26 \mathrm{~m}^{2} / \mathrm{g}$ and acidity of $14 \mathrm{meq} / \mathrm{g}$. These values increase, respectively, to $456.14 \mathrm{~m}^{2} / \mathrm{g}$ and $50 \mathrm{meq} / \mathrm{g}$ for Cat 1 and to $475.12 \mathrm{~m}^{2} / \mathrm{g}$ and $57 \mathrm{meq} / \mathrm{g}$ for Cat 2 . The influence of the type of oxide incorporated, the specific surface area, the porosity and the acidity of the catalysts on their catalytic activity was studied. The nature of the oxide used proved to be decisive on the quality of the catalyst. Thus Cat1, prepared with lanthanum oxide, showed the best performance in cracking the petroleum residue achieving a conversion rate of $74.13 \%$ compared to $66.53 \%$ for cat 2 .
\end{abstract}

Keywords Petroleum residue $\cdot$ Clay $\cdot$ Catalyst $\cdot$ Catalytic cracking

\section{Introduction}

Due to its impact on the environment, the use of heavy oil residue (fuel) is strongly discouraged by government officials. Thus, the demand of fuel will suffer a sharp drop in coming years in favor of gasoline, diesel and other petroleum products, which are lighter. To remain competitive and give added value to heavy oil residues, the refineries are stepping up their research to improve the fluid catalytic cracking (FCC) process $[9,19]$. The FCC process consist to convert heavy oil feeds into light products. Although this process has been used in refineries for decades, it needs to

Soumahoro Gueu

Soumahoro.gueu@inphb.ci

1 Laboratoire des Procédés Industriels, de Synthèse, de L'Environnement et des Energies Nouvelles (LAPISEN), Institut National Polytechnique Félix Houphouët-Boigny, Yamoussoukro BP 1093 Yamoussoukro, Côte d'Ivoire

2 Département Energies Fossiles, Université D’Agadez, BP 199 Agadez, Niger

3 Département de Chimie, Faculté Des Sciences Et Techniques, Université Abdou Moumouni de Niamey, BP 10662 Niamey, Niger be innovate to achieve performance [2,25]. Therefore, new catalyst development need to be investigated to improve the yield of FCC processes.

A catalyst is a substance that increases the rate of a chemical reaction, without being consumed or produced [8]. The activity and selectivity of the FCC catalyst are derived from the acidic sites and the pore structure, respectively. Catalytic catalysts are therefore porous solids with acidic properties $[4,18,23]$. Commercial FCC catalysts generally consist of two main components: the zeolite and the matrix. The zeolites used in FCC catalysts are mainly synthetic faujasite $\mathrm{Y}$ type zeolites and high silica $\mathrm{Y}$ zeolites, which are the main contributor to the catalytic activity and selectivity of the FCC catalyst [13]. The matrix is made of different constituents such as aluminosilicates and additives which are solid compounds added to improve its properties [4, 9]. Nevertheless, the high cost of these commercial catalysts could be a barrier to their use in development countries. It is urgent to develop a novel FCC catalyst with local resource [20,26].

Recent research is directed towards the development of semi-synthetic clay-based catalysts. In this configuration, the clay acts as a matrix in which metallic oxides are incorporated. Emam [8] has shown that clay catalysts are arousing much interest for catalytic application in the 
petroleum refining industry. According to Bouras [6], the interest given in recent years to the study of clays by laboratories around the world is explained by their abundance in nature, the importance of their specific surface, their porosity and especially their ability to exchange interfoliar cations. Kaolin and montmorillonite are the most commonly used clays in the development of refining catalysts [20]. Murray [21] estimates that more than 200,000 tonnes of kaolin are used annually to produce petroleum cracking catalysts. This work deals with the development of new semi-synthetic catalysts based on clay and oxides, the characterization of these catalysts obtained and finally their use in fuel cracking. To our knowledge, in the literature, it has not been reported cracking of fuel oil by semi-synthetic catalysts or even by conventional catalytic catalysts. This study therefore aims to fill this void.

The objective of the current work was to prepare a FCC catalyst, and to study the catalytic properties. Two catalysts were prepared using a kaolinite rich clay as matrix. The influence of the type of oxide incorporated, the specific surface area, the porosity and the acidity of the catalysts on their catalytic activity was studied.

\section{Materials and methods}

\section{Materials}

The catalysts prepared in this study were made from Niger clay. This clay has been characterized in previous work [1]. It has a specific surface area of $15.26 \mathrm{~m}^{2} / \mathrm{g}$ and a loss on ignition of $16.1 \%$. It is mainly composed of kaolinite $(46.3 \%)$ and an interstratified smectite illite chlorite (53.7\%) [1]. The choice of this clay is explained because the catalytic reactions taking place at high temperature $\left(\geq 500{ }^{\circ} \mathrm{C}\right)$, the catalyst must be a refractory material, able to withstand such temperature.

\section{Catalyst preparation}

In a beaker containing $15 \mathrm{~g}$ of clay with a particle size less than $2 \mu \mathrm{m}, 0.55 \mathrm{~g}$ of lanthanum $\left(\mathrm{La}_{2} \mathrm{O}_{3}\right)$ or chromium $\left(\mathrm{Cr}_{2} \mathrm{O}_{3}\right)$ oxide and $4 \mathrm{~g}$ of silica are added. After homogenization, acid activation is carried out by adding $25 \mathrm{~mL}$ of $10 \%$ hydrochloric acid and then the whole is left under stirring for 6 hours. The resulting mixture is dried at $105{ }^{\circ} \mathrm{C}$ for 12 hours and then calcined at $800{ }^{\circ} \mathrm{C}$ for thirty minutes. The catalyst containing lanthanum oxide is called Cat 1 and the one obtained with chromium oxide is called Cat2.

\section{Catalyst characterization}

X-ray diffraction (XRD) patterns of all samples were recorded at room temperature, using a Rigaku-Miniflex II diffractometer (Japan). The incident radiation is generated by the $\mathrm{K} \alpha$ line of copper $(\lambda=1.5406 \AA)$ at $30 \mathrm{kV}$ and $15 \mathrm{~mA}$. The analyzes were carried out in the angular interval $\left[5-70^{\circ}\right]$ in $2 \theta$ with a step of $0.02^{\circ}(2 \theta)$ and a counting time of $2 \mathrm{~s}$.

The infrared spectroscopic analyzes were carried out in ATR (Attenuated Total Reflectance) mode with a Fourier Bruker Alpha Transform spectrometer equipped with a diamond crystal (refractive index of the diamond 2.451). The spectra were acquired with a nominal resolution of $4 \mathrm{~cm}^{-1}$ over a wavenumber range from 400 to $4000 \mathrm{~cm}^{-1}$.

Chemical analysis of the samples was performed using a Vista Pro Varian instrument equipped with an ICP-OES (Inductively Coupled Plasma-Optical Emission Spectroscopy) plasma.

The BET isotherms were obtained using a Nova Station B sorptiometer. The absorption gas used is nitrogen and the measurements are carried out at $77.350 \mathrm{~K}$. The determination of the microporous volumes and the microporous surfaces are carried out by the t-plot method.

A variable pressure scanning electron microscope (SEM) from the D.C.A.R. (SEM FEG Supra 40 VP Zeiss) of $2 \mathrm{~nm}$ resolution coupled to an X-ray microanalyzer (EDS) was used for the characterization of the microstructure and the surface chemical composition of the catalysts.

The total acidity of the catalysts was determined using the titration method of Boehm [5] which is used by many researchers working on adsorbents [12]. This method consists of assaying functional groups having various acidities with different bases. For the present study, the bases used are sodium hydroxide $(\mathrm{NaOH})$, sodium hydrogen carbonate $\left(\mathrm{NaHCO}_{3}\right)$ and sodium ethanolate $\left(\mathrm{C}_{2} \mathrm{H}_{5} \mathrm{ONa}\right)$. The procedure is as follows: a mass of $500 \mathrm{mg}$ of catalyst is placed in Erlenmeyer flasks. Then $25 \mathrm{~mL}$ of the different bases, all prepared at $0.1 \mathrm{~N}$, are transferred into each of the Erlenmeyer flasks containing the catalysts. The blank tests are carried out by proceeding in the same manner, with the difference that Erlenmeyer flasks do not contain a catalyst. The samples and the blanks are stirred on magnetic stirrers at $150 \mathrm{rpm}$ for 72 hours at room temperature, then left to stand for 6 hours. The supernatant is filtered through a Whatman cellulose nitrate membrane $(0.2 \mu \mathrm{m})$ then the excess basic solution is dosed back with a $0.1 \mathrm{~N} \mathrm{HCl}$ solution.

\section{Catalytic cracking test}

The performance tests of the catalysts were carried out in a stainless steel reactor (Fig. 1), manufactured in the 
Fig. 1 Model of the cracking plant
(1) Temperature controller
(2) Furnace
(3) Reactor
(4) Feed
(9) Receiving bottle
(5) Pressure gauge
(6) Pipe for cracked products
(7) Cooling column
(8) Cooling system

(6)

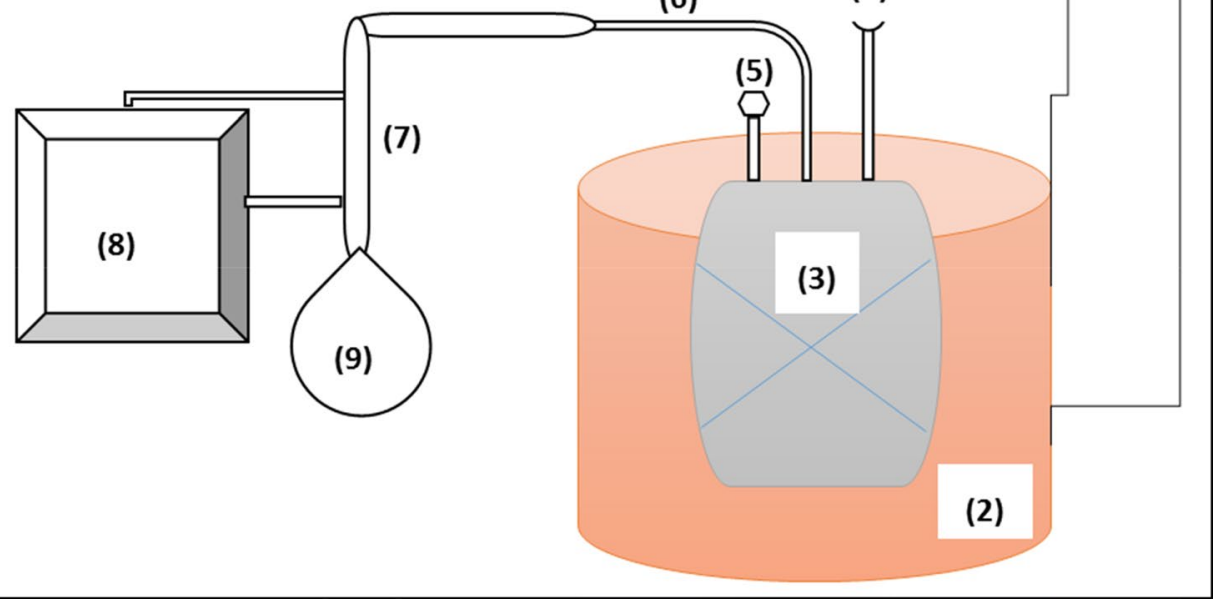




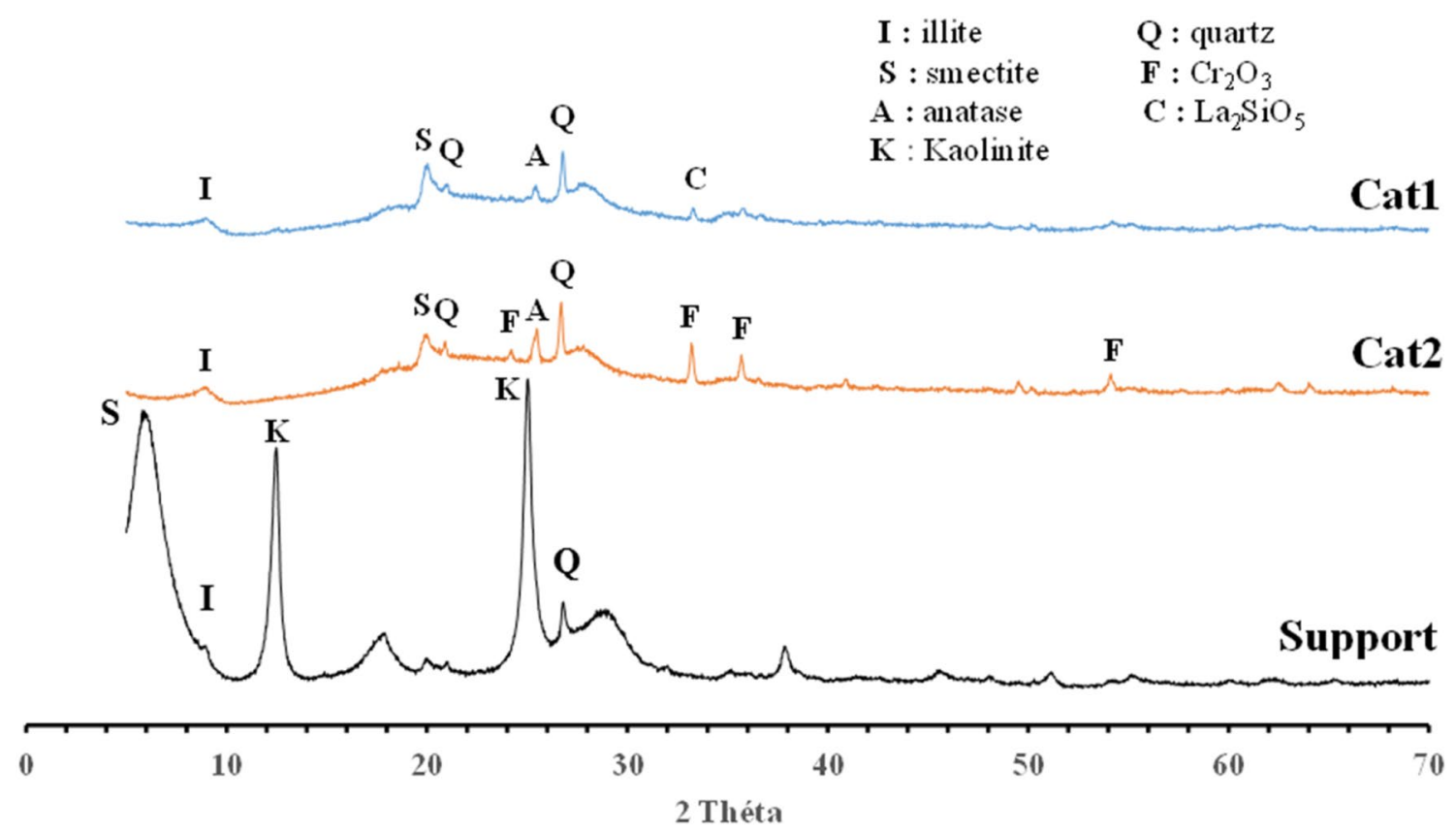

Fig. 2 XRD pattern of clay (support) and catalysts

$\mathrm{La}_{2} \mathrm{O}_{3}+\mathrm{SiO}_{2} \rightarrow \mathrm{La}_{2} \mathrm{SiO}_{5}$

The characteristic phases of chromium oxide $\left(\mathrm{Cr}_{2} \mathrm{O}_{3}\right)$ have been identified on this spectrum. They correspond to the peaks at $54.14^{\circ}$; and $64.04^{\circ}(2 \theta)$ according to Karimi [17].

\section{FTIR spectroscopy}

The Fig. 3 shows the IR spectra of the clay (support) and the two catalysts produced. The spectrum of the support is characteristic of a clay. It shows the deformation vibration modes of structural hydroxyl groups between 950 and

-Support -Cat2 Cat1

(c)

(b)

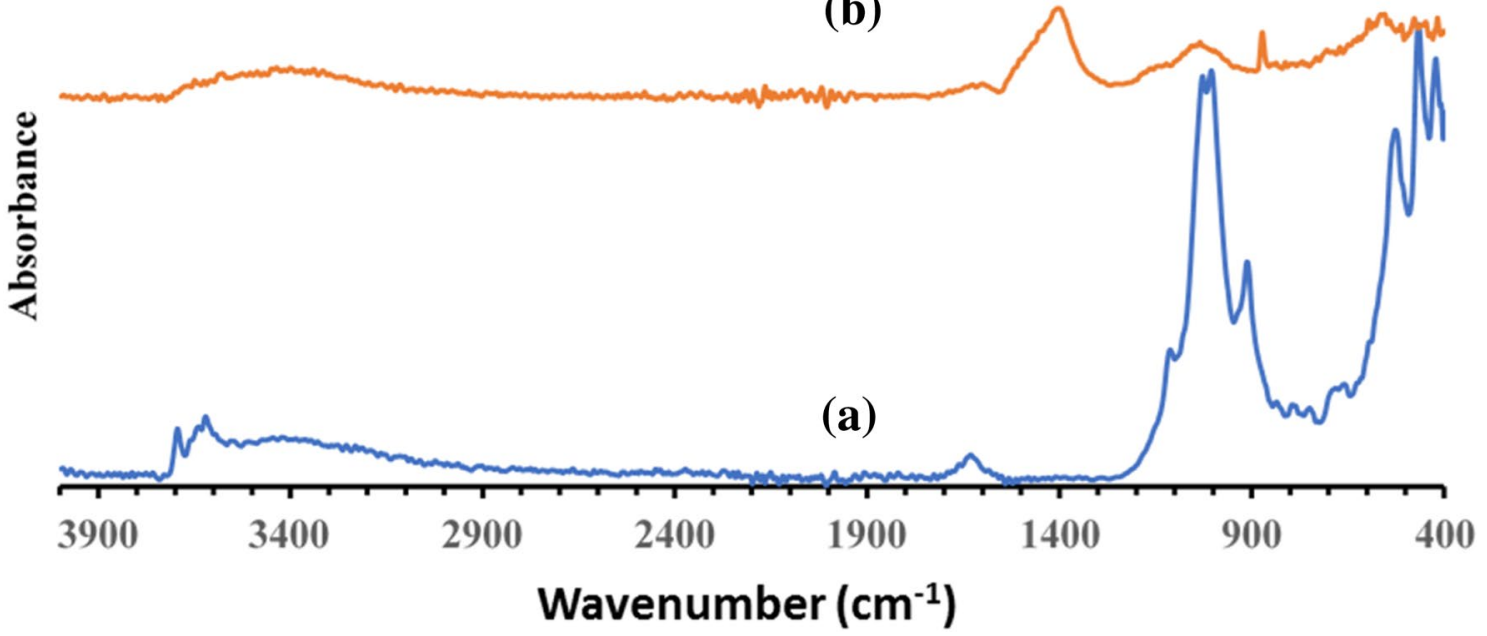

Fig. 3 IR spectra a support, b Cat1, c Cat2 
$800 \mathrm{~cm}^{-1}$. The absorption bands observed at wavenumbers $1034,1100 \mathrm{~cm}^{-1}$ and $1159 \mathrm{~cm}^{-1}$ are characteristic of the antisymmetric modes of elongation of $\mathrm{Si}-\mathrm{O}$ and $\mathrm{Al}-\mathrm{O}$ bonds in aluminosilicates [10]. A comparative analysis of the spectrum of the support and those of the catalysts shows a remarkable change in structure. The difference observed could be related on the one hand to the new elements that were added in the preparation and on the other hand to the calcination that the catalysts underwent. The absorption band at $500 \mathrm{~cm}^{-1}$ is attributed to the vibration mode of the $\mathrm{La}-\mathrm{O}$ bond of lanthanum oxide according to Saravani and Khajehali [28]. This peak confirms the presence of $\mathrm{La}_{2} \mathrm{O}_{3}$ phase in the Cat 1 sample. The bands observed around 581 and $647 \mathrm{~cm}^{-1}$ are characteristic absorption bands of $\mathrm{Cr}_{2} \mathrm{O}_{3}$ on the Cat2 spectrum according to Nguyen et al. [22].

\section{Catalyst acidity}

The acidity of the catalysts measured by Boehm method indicates higher values of acidity for the catalysts compared to that of the support. Initially equal to $14 \mathrm{meq} / \mathrm{g}$ for the support, the acidity was evaluated at $50 \mathrm{meq} / \mathrm{g}$ for Cat 1 and $57 \mathrm{meq} / \mathrm{g}$ for Cat2. This significant increase could be justified by the presence of oxides which were added during processing. These acidity values are lightly superiors to those of the FCC zeolite catalysts (30-50 meq/g) used by Ibarra et al. [16]. This suggests that the catalysts developed here would be efficient in cracking test as industrial catalysts from the point of view of surface acidity.

\section{Chemical analysis}

The chemical analysis of catalysts are given in Table 1 . The $\mathrm{SiO}_{2} / \mathrm{Al}_{2} \mathrm{O}_{3}$ ratio of the support was equal to 2.08 , similar to that obtained by Gueu et al. [11]. The $\mathrm{SiO}_{2}$ content in Cat 1 and Cat 2 catalysts are $59.1 \%$ and $61.9 \%$ respectively. This content was initially equal to $49 \%$ in the support. The observed increase is due to the addition of silica during the preparation of the catalysts. According to Otmani [24], silica give good mechanical strength to catalysts and increase their acidic character [18] for the catalytic cracking operation. Furthermore, the $\mathrm{SiO}_{2}$ contents of the catalysts are higher than that of the commercial FCC catalyst (54.1\%) used by
Hussain et al. [15] for the catalytic cracking of vacuum gas oil.

\section{Textural analysis}

\section{Specific surface}

The specific surfaces of the catalysts produced were evaluated by the method of Brunauer, Emmet and Teller (B. E. T). They are $456.14 \mathrm{~m}^{2} / \mathrm{g}$ and $475.12 \mathrm{~m}^{2} / \mathrm{g}$ for the Cat1 and Cat2 respectively. The results obtained show that the surfaces have increased considerably compared to the specific surface of the clay support $\left(15.26 \mathrm{~m}^{2} / \mathrm{g}\right)$. This is due to the acid activation performed during formulation. This considerable increase is also observed in the literature [3, $13]$ and reflects a significant development of microporosity. The values obtained in this study are better than $347 \mathrm{~m}^{2} / \mathrm{g}$ and $177 \mathrm{~m}^{2} / \mathrm{g}$, representing the surface areas calculated by He et al. [13] and Al-Khattaf [3] respectively. In addition, Ribeiro et al. [27] found specific surface areas of 266, 276 and $422 \mathrm{~m}^{2} / \mathrm{g}$ for commercial FCC catalysts which are also lower than those of the catalysts developed here. These results once again show the good characteristics developed by the catalysts prepared in this work.

\section{Porosity}

The porosity of the catalyst is a very important factor. It is established that the diffusion of molecules from the residue to be cracked is easy when the dimensions of the pore are 2-6 times larger than those of the molecules [30]. The data (Table 2) show that the diameters and the pore volumes increased considerably after the preparation of the catalysts. The type of oxide used does not influence the pore diameter which remained similar for

Table 2 Pore diameters and volumes of prepared catalysts

\begin{tabular}{lll}
\hline Catalysts & $\begin{array}{l}\text { Average pore diam- } \\
\text { eter }(\mathrm{nm})\end{array}$ & Pore volume $\left(\mathrm{cm}^{3} / \mathrm{g}\right)$ \\
\hline Support & 0.75 & 0.18 \\
Cat1 & 2.12 & 0.49 \\
Cat2 & 2.15 & 0.24 \\
\hline
\end{tabular}

Table 1 Chemical analysis of catalysts

\begin{tabular}{lllllllllllll}
\hline \multicolumn{1}{c}{ Chemical composition (\%) } \\
\cline { 2 - 10 } & $\mathrm{SiO}_{2}$ & $\mathrm{Al}_{2} \mathrm{O}_{3}$ & $\mathrm{Fe}_{2} \mathrm{O}_{3}$ & $\mathrm{MgO}$ & $\mathrm{TiO}_{2}$ & $\mathrm{CaO}$ & $\mathrm{Na}_{2} \mathrm{O}$ & $\mathrm{K}_{2} \mathrm{O}$ & $\mathrm{P}_{2} \mathrm{O}_{5}$ & $\mathrm{La}$ & $\mathrm{Cr}$ & $\mathrm{LOI}^{\mathrm{a}}$ \\
\hline Sup-port & 49 & 23.5 & 4.1 & 2.19 & 1.35 & 1.76 & 0.45 & 0.93 & 0.3 & - & - & 16.1 \\
Cat1 & 59.1 & 19.1 & 3.31 & 1.44 & 1.18 & 0.5 & 1.21 & 0.63 & 0.25 & 2.5 & 0.01 & 7.5 \\
Cat2 & 61.9 & 19.4 & 4.52 & 1.76 & 1.13 & 2.05 & 0.37 & 0.77 & 0.24 & 0.01 & 0.01 & 5.3 \\
\hline
\end{tabular}

${ }^{\mathrm{a}}$ Loss on ignition 
the two catalysts. The pore volume developed by Cat 1 is significantly greater than that of Cat 2 .

\section{SEM}

The images obtained by scanning electron microscopy (SEM) and X-ray microanalysis of the catalysts are presented in Figs. 4 and 5.
Fig. 4 SEM image and X-ray microanalysis of Cat 1

Fig. 5 SEM image and X-ray microanalysis of Cat2
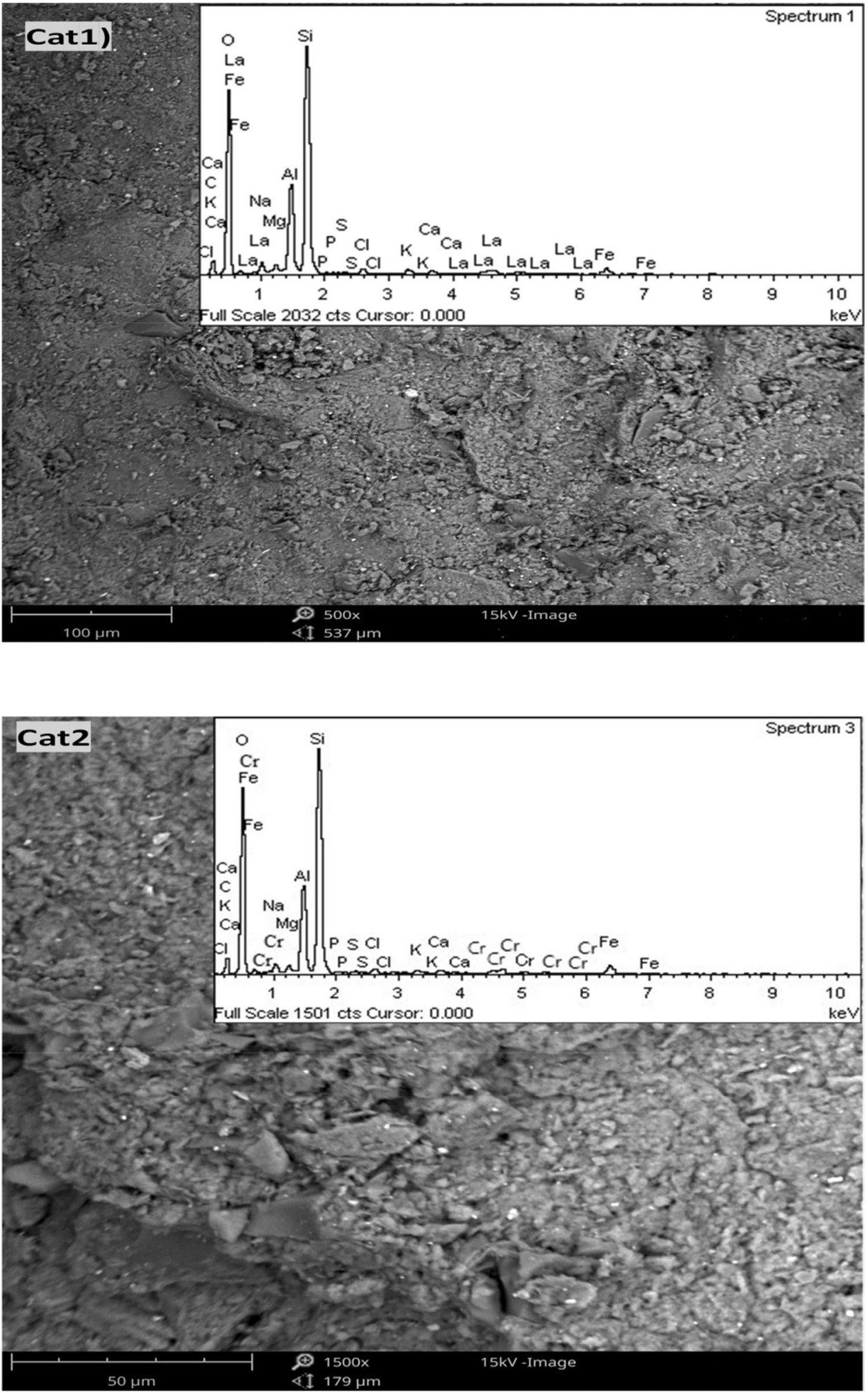
Figures 4 and 5 show that the catalysts mostly consist of very fine particle clusters. These images show a certain homogeneity in the composition of the samples. However, the Fig. 4 shows clusters in the form of aggregates. This particularity could be justified by an incomplete grinding of the Cat 1 sample during its SEM preparation. In addition, grains of quartz $\left(\mathrm{SiO}_{2}\right)$ are also observed on these images. This confirms the above analyses.

The results of the X-ray microanalysis of the catalysts indicate the presence of several elements such as silicon ( $\mathrm{Si}$ ) which is the most abundant element in all samples. It's to be note the appearance of lanthanum (La) in Fig. 4 and the appearance of the element chromium $(\mathrm{Cr})$ in Fig. 5. The presence of these elements ( $\mathrm{La}$ and $\mathrm{Cr}$ ) confirms the incorporation of the oxides.

\section{Catalytic cracking yield}

The catalysts developed here were used in the cracking of a petroleum residue. The cracking tests take place at $500{ }^{\circ} \mathrm{C}$ with a ratio fuel/catalyst $(\mathrm{g} / \mathrm{g})$ equal to 4.5 . The results recorded show a conversion rate of 74.13 and $66.53 \%$ for the Cat 1 and Cat 2 respectively. The acidity of the catalysts is very often considered to be the most important parameter. The greater the activity, the greater the catalytic efficiency. This assertion is not verified in this study. Indeed, despite its low acidity, Cat 1 has the best yield. This would be attribute to its specific surface area and its pore volume which are high than those measured for Cat2.

\section{Conclusion}

The objective of this work was to develop clay-based catalysts to crack a heavy oil residue. XRD and infrared analyzes of the prepared catalysts confirmed the presence of lanthanum oxide and chromium oxide. This indicates that the oxides have been well incorporated showing at the same time that the method of preparation is suitable. Textural analysis showed that the incorporation of oxide, acid activation and calcination carried out during processing strongly influenced the composition and textural properties of the catalysts. The specific surfaces increase from $15.26 \mathrm{~m}^{2} / \mathrm{g}$ for the support to 456.14 and $475.12 \mathrm{~m}^{2} / \mathrm{g}$ for the Cat 1 and Cat2 respectively. Pore volumes also increased from $0.18 \mathrm{~cm}^{3} / \mathrm{g}$ for the support to $0.49 \mathrm{~cm}^{3} / \mathrm{g}$ and $0.24 \mathrm{~cm}^{3} / \mathrm{g}$ for Cat 1 and Cat 2 respectively. Compared to the support, the acidities of the two catalysts are very higher. This was related to the addition of silica and acidic activation made during catalysts preparation. Finally, the catalytic cracking results indicated a conversion rate of 74.13 and $66.53 \%$ for Cat 1 and Cat 2 respectively. From this study, the use of this clay for the development of semi-synthetic catalysts would be particularly interesting to the refining industry.

Open Access This article is licensed under a Creative Commons Attribution 4.0 International License, which permits use, sharing, adaptation, distribution and reproduction in any medium or format, as long as you give appropriate credit to the original author(s) and the source, provide a link to the Creative Commons licence, and indicate if changes were made. The images or other third party material in this article are included in the article's Creative Commons licence, unless indicated otherwise in a credit line to the material. If material is not included in the article's Creative Commons licence and your intended use is not permitted by statutory regulation or exceeds the permitted use, you will need to obtain permission directly from the copyright holder. To view a copy of this licence, visit http://creativecommons.org/licenses/by/4.0/.

\section{References}

1. Abdoulaye ODM, Yao BK, Ahmed AM, Adouby K, Abro DMK, Drogui P (2019) Mineralogical and morphological characterization of a clay from Niger

2. Akah A (2017) Application of rare earths in fluid catalytic cracking: a review. J Rare Earths 35:941-956

3. Al-Khattaf S (2003) The influence of alumina on the performance of FCC catalysts during hydrotreated VGO catalytic cracking. Energy Fuels 17:62-68

4. Avidan AA (1993) Origin development and scope of FCC catalysis in: studies in surface science and catalysis. Elsevier

5. Boehm HP (1966) Chemical identification of surface groups in: advances in catalysis. Elsevier

6. Bouras O (2003) Propriétés adsorbantes d'argiles pontées organophiles: synthèse et caractérisation (PhD Thesis). Limoges

7. Djoudi L (2016) Synthese et propriétés d'oxydes mixtes a base de lanthane, aluminium et Nickel ( $\mathrm{PhD}$ Thesis). Université Mohamed Khider-Biskra

8. Emam EA (2013) Clays as catalysts in petroleum refining industry. ARPN J Sci Technol 3:356-375

9. Feng R, Qiao K, Wang Y, Yan Z (2013) Perspective on FCC catalyst in China. Appl Petrochem Res 3:63-70. https://doi. org/10.1007/s13203-013-0030-1

10. Goodman BA, Russell JD, Fraser AR, Woodhams FWD (1976) A Mössbauer and IR spectroscopic study of the structure of nontronite. Clays Clay Miner 24:53-59

11. Gueu S, Finqueneisel G, Zimny T, Bartier D, Yao BK (2019) Physicochemical characterization of three natural clays used as adsorbent for the humic acid removal from aqueous solution. Adsorpt Sci Technol 37:77-94. https://doi.org/10.1180/ clm.2020.26

12. Gueu S, Yao B, Adouby K, Ado G (2006) Heavy metals removal in aqueous solution by activated carbons prepared from coconut shell and seed shell of the palm tree. JApSc 6:2789-2793. https:// doi.org/10.3923/jas.2006.2789.2793

13. He L-J, Zheng S-Q, Dai Y-L (2017) Povećanje iskorištenja benzina katalizatorom za krekiranje u fluidiziranom sloju (FCC). Kemija industriji 66:9-15

14. Houdry EJ (1953). Process for catalytically cracking hydrocarbons

15. Hussain AI, Aitani AM, KubluuČejkaAl-Khattaf MJS (2016) Catalytic cracking of Arabian light VGO over novel zeolites as FCC catalyst additives for maximizing propylene yield. Fuel 167:226-239 
16. Ibarra Á, Hita I, Azkoiti MJ, Arandes JM, Bilbao J (2019) Catalytic cracking of raw bio-oil under FCC unit conditions over different zeolite-based catalysts. J Ind Eng Chem 78:372-382. https ://doi.org/10.1016/j.jiec.2019.05.032

17. Karimi N (2007) Etude par diffraction des rayons X in situ des mécanismes d'oxydation de l'acier AISI 304 entre $800{ }^{\circ} \mathrm{C}$ et $1000{ }^{\circ} \mathrm{C}$. Influence des dépôts sol-gel de lanthane et de cérium. Apport de la spectroscopie infrarouge à l'identification des oxydes mixtes ( $\mathrm{PhD}$ Thesis)

18. Leprince $P(1998)$ Le raffinage du pétrole: procédés de transformation. Technip, Paris, p 550

19. Liu Z, Zhang Z, Yang C, Gao X (2015) Domestic technology developments on high-efficiency heavy oil conversion FCC catalysts' industrialization. Appl Petrochem Res 5:269-275. https:// doi.org/10.1007/s13203-015-0133-y

20. Mamudu A, Emetere M, Okocha D, Taiwo S, Ishola F, Elehinafe F, Okoro E (2020) Parametric investigation of indigenous Nigeria mineral clay (Kaolin and Bentonite) as a filler in the Fluid Catalytic Cracking Unit (FCCU) of a petroleum refinery. Alexandria Eng J 59:5207-5217. https://doi.org/10.1016/j.aej.2020.09.050

21. Murray HH (2006) Applied clay mineralogy: occurrences, processing and applications of kaolins, bentonites, palygorskitesepiolite, and common clays. Elsevier

22. Nguyen TP, Jonnard P, Vergand F, Staub PF, Thirion J, LapkowskiTran MVH (1995) Characterization of the poly (paraphenylene vinylene)-chromium interface by attenuated total reflection infrared and X-ray emission spectroscopies. Synth Met 75:175-179

23. Olaremu AG, Adedoyin WR, Ore OT, Adeola AO (2021) Sustainable development and enhancement of cracking processes using metallic composites. Appl Petrochem Res. https://doi. org/10.1007/s13203-021-00263-1

24. Otmani S (2006) Valorisation des charges lourdes compoundées par le craquage catalytique ( $\mathrm{PhD}$ Thesis)

25. Pouwels C, Bruno K (2013) FCC catalyst design evolves to maximize propylene. Hydrocarbon Process

26. Qureshi MS, Nisar S, Shah R, Salman H (2020) Studies of liquid fuel formation from plastic waste by catalytic cracking over modified natural clay and nickel nanoparticles 10. Pakistan J Sci Ind Res 63(2):79

27. Ribeiro AM, Machado Júnior HF, Costa DA (2013) Kaolin and commercial fcc catalysts in the cracking of loads of polypropylene under refinary conditions. Braz J Chem Eng 30:825-834

28. Saravani H, Khajehali M (2016) Synthesis and characterization of lanthanum oxide and lanthanumoxid carbonate nanoparticles from thermalizes of [ $\mathrm{La}($ acacen $)\left(\mathrm{NO}_{3}\right)\left(\mathrm{H}_{2} \mathrm{O}\right)$ complex. Orient $\mathbf{J}$ Chem 32:491-498. https://doi.org/10.13005/ojc/320156

29. Sun F (2010) Caractérisation de revêtements de silicate de lanthane de structure apatite dopé au magnésium réalisés par projection plasma en vue d'application comme électrolyte de pile à combustible de type IT-SOFC (PhD Thesis)

30. Zhang Z, Liu Z, Feng R, Liu P, Yan Z (2014) The development of FCC catalysts for producing FCC gasoline with high octane numbers. Appl Petrochem Res 4:379-383

Publisher's Note Springer Nature remains neutral with regard to jurisdictional claims in published maps and institutional affiliations. 